\title{
Research Paper \\ Identifying the structure and coordinates of the curriculum of indigenous arts in the second elementary school of sistan region
}

Maryam Keykha', Marjan Kian' ${ }^{2}$ Effat Abbasi $^{3}$, Majid AliAsgari
1. Ph.D Student in Curriculum, Faculty of Psychology and Educational Sciences, Kharazmi University, Tehran, Iran.
Tehran, Iran.
2. Associate Professor, Department of Curriculum Studies, Faculty of Psychology and Educational Sciences, Kharazmi University,
Tehran, Iran.

Citation: Keykha M, Kian M, Abbasi E, AliAsgari M. Identifying the structure and coordinates of the curriculum of indigenous arts in the second elementary school of sistan region. J of Psychological Science. 2021; 20(104): 1267-1278.
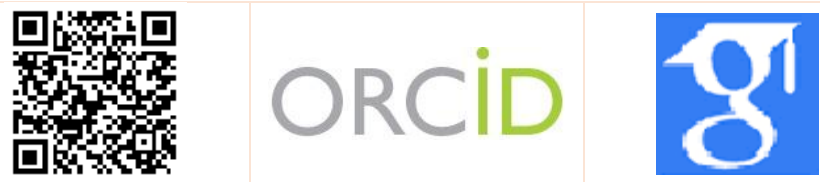

URL: https://psychologicalscience.ir/article-1-1368-fa.html

$\underline{10.52547 / J P S .20 .104 .1267}$

\section{A R T I C L E I N F O A B S T R A C T}

Keywords:

Curriculum, IndigenousArts, Second Grade

Received: 09 Aug 2021 Accepted: 01 Sep 2021 Available: 23 Oct 2021
Background: Empowering students by teaching professional skills appropriate to local conditions and general skills of employment and entrepreneurship, such as art curriculum based on indigenous arts of the province can be a suitable subject and activity for this work. But due to lack of support, many traditional arts in various parts of Iran, including Sistan, are declining or in disarray.

Aims: The aim of this study was done to identify the components of the curriculum of indigenous arts in Sistan region in the second elementary school period.

Methods: The research was conducted in two stages with a qualitative research method. In the first stage, available documents, articles and written sources related to the subject were examined by data mining method and data was collected and this data collection continued until the stage of theoretical saturation. The data analysis of this step was done through thematic coding. In the second stage of the research, phenomenological method was used to study the life experiences of local artists in Sistan region. At this stage, the participants were selected by criterion-based purposive sampling, data collection tools, semi-structured interviews and information analysis by Claizey (1978).

Results: Based on research findings; 7 components of objectives, content, memory-learning, materials and resources, space and place, time and evaluation were extracted as components of the native arts curriculum of Sistan region. According to the results of the present study in Sistan region, the elements of the curriculum (objectives, content, teaching methods, teaching materials and resources, time, place and evaluation) and the role of each of these elements on art education, skills development, knowledge, ability And Attitudes, Creativity, Academic Success, Strengthening Communication, Verbal and Motor Skills, Five Senses, Developing Students 'Thinking Capacity, and Students' Social, Cultural, and Academic Education Using Art and Preparing Programs That Educate Make it attractive, enjoyable and effective; Be emphasized.

Conclusion: Pay attention to indigenous knowledge, preserving and promoting indigenous and local knowledge and identity, cultivating the spirit of aesthetics and developing existential capabilities are necessary for artistic expression in the indigenous art curriculum of Sistan region, and more research is needed to realize and implement it. In this regard.

* Corresponding Author: Marjan Kian, Associate Professor, Department of Curriculum Studies, Faculty of Psychology and Educational Sciences, Kharazmi University, Tehran, Iran.

E-mail: kian@khu.ac.ir

Tel: (+98) 9128023514

2476-5740/ (C) 2021 The Authors. This is an open access article under the CC BY-NC-ND license

(https://creativecommons.org/licenses/by-nc/4.0/). 


\section{Extended Abstract}

\section{Introduction}

In recent years, international organizations, education ministers, and planners around the world have emphasized the social benefits of art education and its contribution to economic, social, development, fighting poverty, promoting public values and cultural understanding, or cultivating local cultural values and identities (Amido and Et al., 2016). Modern curricula seek to provide an aesthetic experience for learners (Walsh, 2019). The national curriculum document has emphasized $20 \%$ of localization of content and curricula with the aim of decentralization. Moreover, one of the most important areas of the school special planning is the teaching of a skill. One of these useful skills is the skill of a lawful living so that students can have the ability to support themselves and run a family when they leave the formal education system. In this regard, empowering students by teaching professional skills appropriate to local conditions and general skills of employment and entrepreneurship, like art curriculum based on indigenous arts of the province, can be a suitable subject and activity for this aim (National Curriculum of the Islamic Republic of Iran, 2012). Researches on this field have included two parts in the country. In the first part, which compares the art in the Iranian educational program with other countries, such as the researches of Kargozar et al. (2017), Ahangari Kalaei et al. (2015) and Khosravi (2014). They conducted a comparative study on Iranian art curricula with Japan, Australia, Canada and the United Kingdom. The results of comparison and evaluation showed that, in our country's educational system, art education has both theoretical and intellectual limitations and executive and practical obstacles and bottlenecks. In the field of practice or implementation of elementary school art curriculum, there is a great distance between Iran and other selected countries in all elements of the curriculum. The second part includes the researches of Ghaffari et al. (2016), Mehrafroozi and Mohammadi (2015), Tahmasbzadeh et al. (2014), Barati and Soleimanpour (2014), Mir Arefin and Mehr Mohammadi (2018), Matinfar and Kian (2017),
Shah Nemati et al. (2015), Garmabi and Maleki (2014), and Amini (2015). They have discussed the status and importance of art lesson in the educational system in the country and the extent of its localization in different parts of the country. Localization of art curriculum in this region of Sistan means full knowledge of the natural environment and people of this region from the past to the present. Thus, the present research seeks to answer the following question: what are the components of the indigenous art curriculum of the second period of elementary school in Sistan? What are the characteristics of the pattern structure of the indigenous art curriculum of the second period of elementary school of Sistan region?

\section{Method}

The present research is naturally qualitative. It has been done in two stages. In the first stage, we used the document mining method and in the second the phenomenological method. Our analysis approach is coding in the first stage and in the second the Colaizzi approach (1978) according to descriptive phenomenology. They include multiple stages from data collection to saturation.

\section{Results}

After coding, conducting interviews and reaching theoretical saturation, we classified the analyzes into two stages and finally we extracted 7 components of the curriculum through the qualitative data content analysis using Atlas software.

These components are:

Objectives, content, learning-teaching strategies, educational materials and resources, space, time and evaluation.

In the following, we present each of the components related to the Sistan region indigenous art curriculum: Curriculum Objectives

some examples of the goals of curriculum and indigenous arts are:

* Cultivating imagination and creativity

* Strengthening the five senses

* Developing artistic literacy

* Paying attention to the interests, talents and needs of students

* National curriculum objectives 
* Preservation of cultural heritage and indigenous traditions

* The wants and needs of the local community

* Preservation, development and growth of indigenous knowledge and identity

Curriculum content

Another important and sensitive element in elementary school education is curriculum content. According to the results of data analysis, they are:

* Paying attention to the characteristics of students from the perspective of aesthetics and art

\section{Learning-teaching strategies}

Based on the results of the analysis, examples of learning-teaching strategies are:

* Project and workshop methods

* Attractive, active and participatory methods

* Providing aesthetic and creative experiences

Educational materials and resources

According to the results obtained from data analysis, the examples of educational materials and resources are:

* Providing the required materials in accordance with the training

Space

Based on the results of data analysis, the characteristics of the learning space are:

* Organizing a place appropriate to teaching indigenous arts based on areas of learning

* Refreshing the physical and even emotional space

* Predicting real spaces for students' free activity and their participation in changing the environment

Time

According to the results of the analysis, manifestations of the introduction of time are:

* Creating constructive competition in organizing art exhibitions

We extracted the model of Sistan region indigenous arts curriculum and its relationship with its components that from qualitative data analysis using Atlas software.

\section{Conclusion}

This research intended to identify the components of the indigenous art curriculum of Sistan region in the second elementary period. Accordingly, we extracted 7 components of objectives, content, teachinglearning, materials and resources, space and place, time and evaluation as components of the indigenous arts curriculum of Sistan region. The results of the present research are consistent with the results of previous researches. They emphasize also the elements of the curriculum (objectives, content, teaching methods, teaching materials and resources, time, place and evaluation), the role of each of these elements in art education, development of skills, knowledge, abilities and attitudes, creativity, academic achievement, strengthening communication, verbal and motor skills, five senses, developing students' thinking ability and students' social, cultural and educational education using art and preparing programs that make education attractive, enjoyable and more effective. In the field of curriculum localization indicators, some researches emphasize the need for localization of curriculum elements and its impact on ethnic cultural identity, knowledge of the culture and customs of different Iranian ethnic groups, as well as strengthening and development of cultural heritage in each region. Nasehian (2016), Haji Tabar Firoozjaei and Mir Arab Arazi (2015), Eskandari Rad and Rasouli (2015), Malekipour and Hakimzadeh (2015), Mortazavi (2011), Sharifzadeh (2008) and Shah Sani (2008).

\section{Ethical Considerations}

Compliance with ethical guidelines: The authors extracted this article from the $\mathrm{PhD}$ dissertation of the first authorin the Faculty of Management, Kharazmi University, Tehran.

Funding: This study was conducted as a $\mathrm{PhD}$ thesis with no financial support.

Authors' contribution: The first author was the senior author, the second were the supervisors and the third and forth was the advisors.

Conflict of interest: The authors declare no conflict of interest for this study.

Acknowledgments: I would like to appreciate the supervisor, the advisors, the participants, and the authorities of Sistan and Baluchestan Education Department. 


\section{شناسايى ساختار و مختصات برنامه درسى هنرهاى بومى دوره دوم ابتدايى منطقه سيستان}

\section{مريم كيخا'، مرجان كيان "، عفت عباسى"، مجيد على عسكرى}

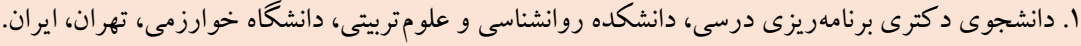

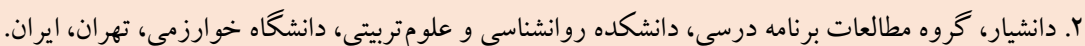

r. استاديار، كروه مطالعات برنامه درسى، دانشكده روانشناسى و علوم تربيتى، دانشكاه خوارزمى، تهران، ايران.

زمينه: تو انمندسازى دانش آموزان با آموزش مهارتهاى حرفه اى متناسب با شرايط محلى و مهارتهاى عمومى اشتغال و كار آفرينى، همجون برنامه درسى هنر مبتى بر هنرهاى بومى استان مى تواند موضوع و فعاليت مناسبى براى اين كار به شمار آيد. اما به دليل عدم حمايت،

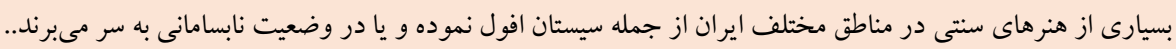
مشخصات مقاله هدف: يُزوهش حاضر با هدف شناسايى مؤلفههاى برنامه درسى هنرهاى بومى منطقه سيستان در دوره دوم ابتدايى انجام گرفت. روش: يُوهش در دو مرحله و با روش يثوهش كيفى انجام يذيرفت. در مرحله اول، اسناد، مقالات و منابع مكتوب در دسترس مرتبط با

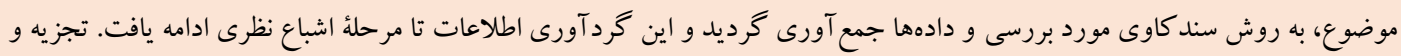
تحليل اطلاعات اين مرحله، از طريق كد گذارى موضوعى صورت بذيرفت. در مرحله دوم يزوهش به منظور بر رسى تجارب زيسته هنرمندان

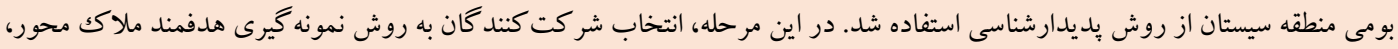
ابزار جمع آورى اطلاعات، مصاحبه نيمه ساختار يافته و روش تجزيه و تحليل اطلاعات روش كلايزى (19VN) بود.

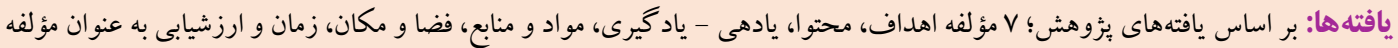
هاى تشكيل دهنده برنامه درسى هنرهاى بومى منطقه سيستان استخراج شدند. طبق نتايج يُزوهش حاضر در منطقه سيستان بايد بر عناصر برنامه درسى (اهداف، محتوا، روش تدريس، مواد و منابع آموزشى، زمان، مكان و ارزشيابى) و نقش هر كدام از اين عناصر بر تربيت هنرى، توسعه بره

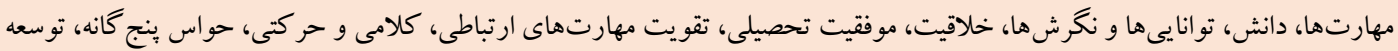

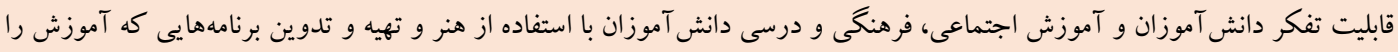
جذاب، لذتبخش و تأثير گذارتر كنند؛ تأكيد شود. نتيجه كيرى: توجه به دانش بومى، حفظ و ارتقاء دانش و هويت بومى و محلى، برورش روحيه زيباشناسى و رشد و برورش قابليتهاى

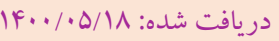
وجودى براى بيان هنرى در برنامه درسى هنر بومى منظقه سيستان ضرورى است و براى تحقق و عملى كردن آن نياز به يزوهشى هاى بيشتر در 
تو سعه دهند، به تجربه هاى هنرى، ساختار هويت فردى، اجتماعى و جهانى

مقلفمه

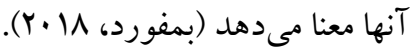

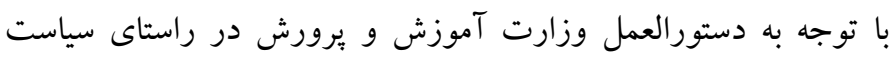

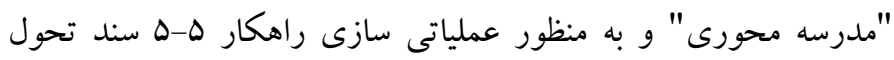

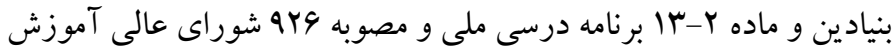
و يرورش، (سند تحول بنيادين آموزش و برورش، •هبا)"برنامه ويزه

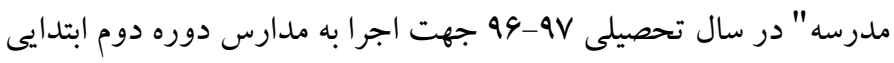

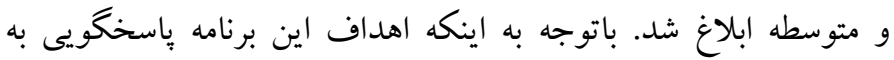

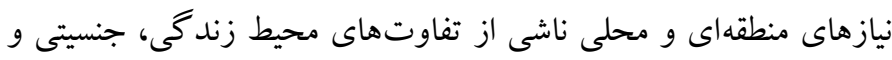

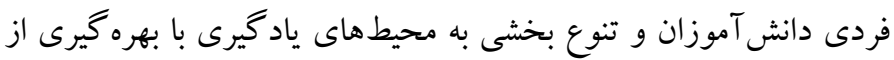

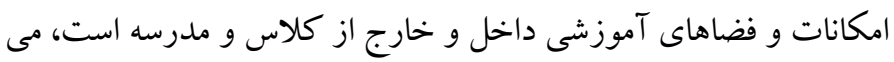
توان از اختيارات اختصاص داده شده به مدرسه جهت برنامهريزى مراحل اين برنامه از انتخاب موضوع تا طراحى، تدوين، اجراو ارزشيابى استفاده

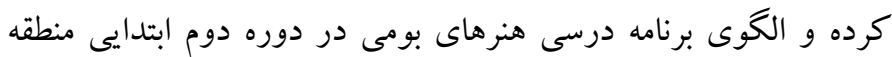

$$
\text { سيستان را طر احى و ارائه نمود. }
$$

با توجه به اين كه در سند برنامه درسى ملى به ·r درصد بومى شدن محتوا

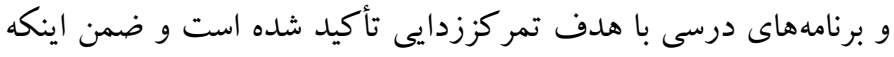

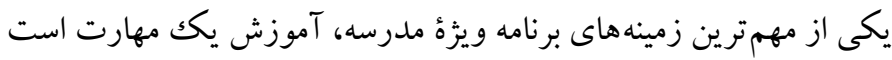

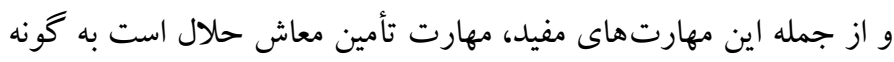

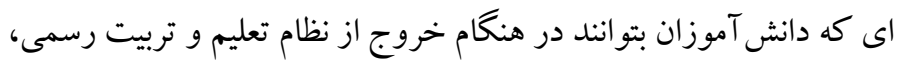

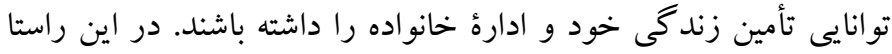

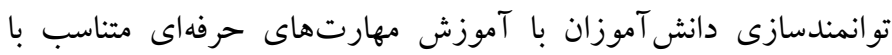
شرايط محلى و مهارتهاى عمومى اشتغال و كار آفرينى، همجيون برنامه مهند درسى هنر مبتنى برهنرهاى بومى استان مى تواند موضوع و فعاليت مناسبى براى اين كار به شمار آيد (برنامه درسى ملى جمهورى بلى اسلامى ايران،

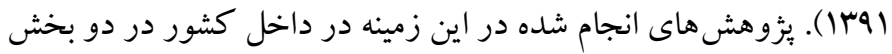
انجام شدهاند. در بخش اول كه در سطح بين المللى به مقايسه موضوع هنر

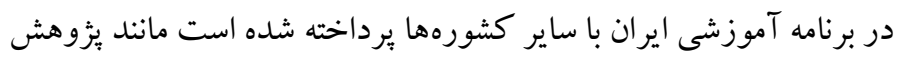

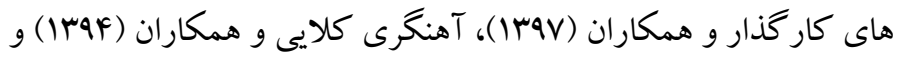

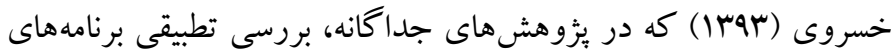

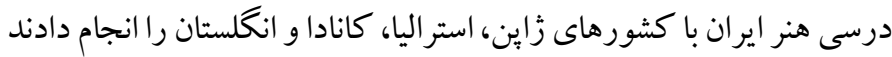
و نتايج مقايسه و ارزيابىها نشان داد كه تربيت هنرى در نظام آموزشى درى
در سالهاى اخير سازمانهاى بينالمللى، وزيران آموزش و بروور و

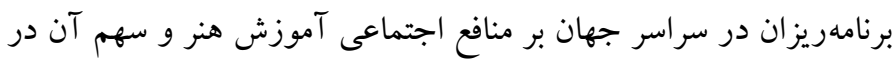

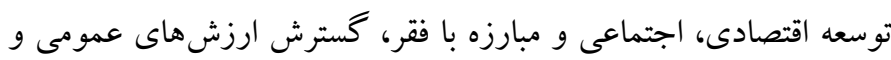

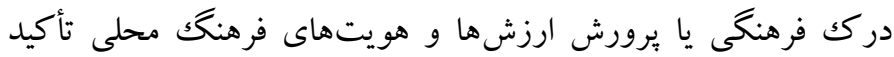

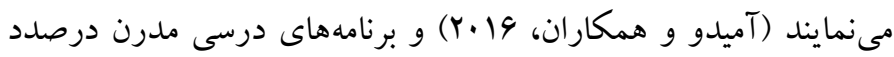

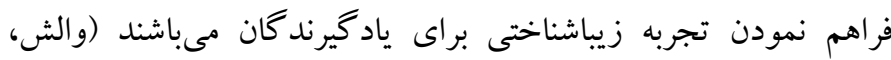

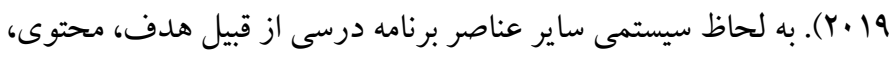

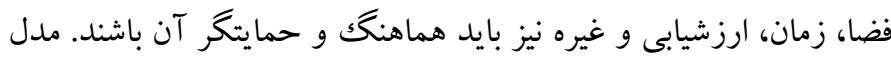

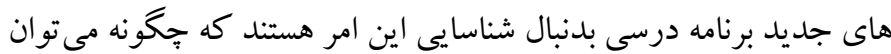

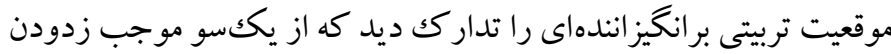

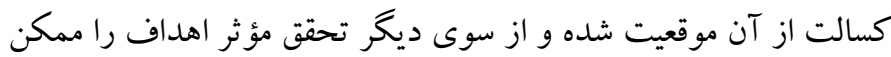

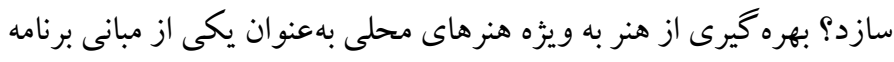

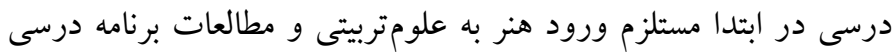
است كه اين كام تا حدودى توسط صاحبنظرانى از قبيل آيزنر، والانس و و

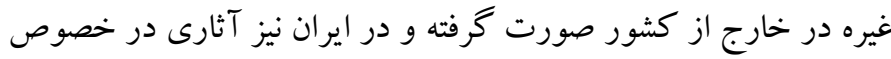

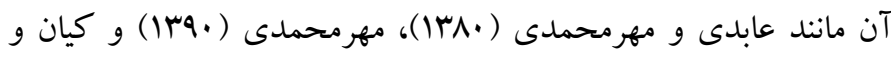

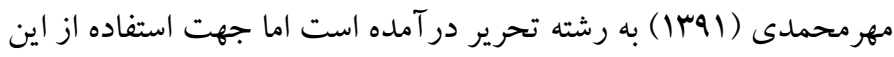

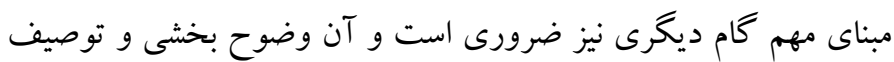

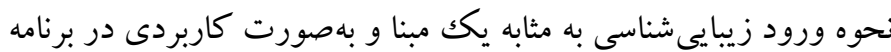
درسى بهصورت عام و در برنامه درسى يكك دوره معين مانند دوره دوم

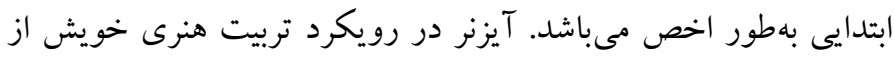

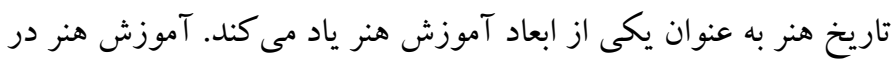
دوره ابتدايى باعث مى شود تا كود كان ترغيب شوند توانيىهاى خود را در

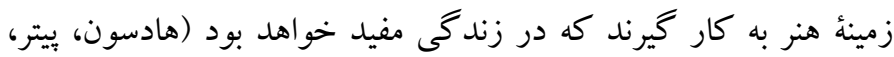

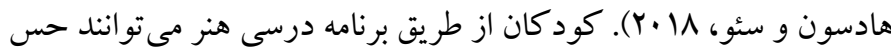
شناختى، فيزيكى، عاطفى، فكرى، زبانى و اخلاقى خود را افزايش دهند

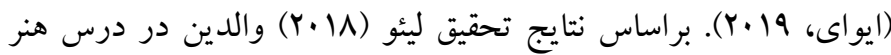

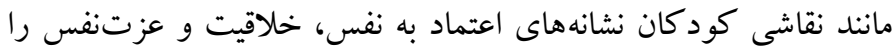

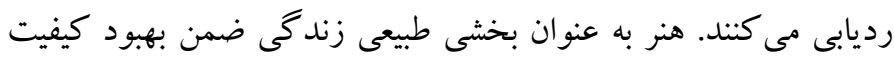

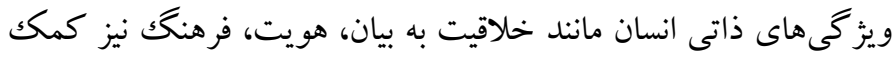

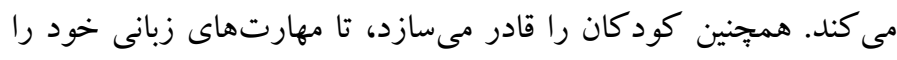


مكتوب در دسترس مرتبط با موضوع، به روش سندكاوى مورد بررسى و

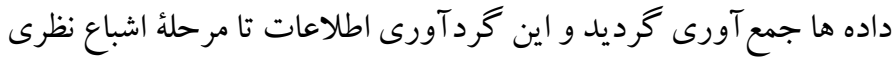

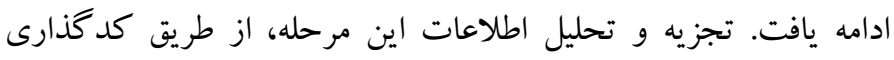
موضوعى صورت يذيرفت. در مر حله دوم يزوهش به منظور بررسى تجارب زيستٔ هنرمندان بومى منطقه سيستان از روش بديدارشناسى استفاده شد. در

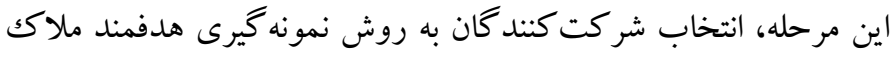

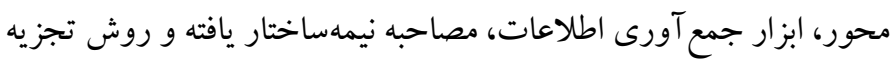
و تحليل اطلاعات روش كلايزى (19VA) بود.

يافته ها يس از كد گذارى و انجام مصاحبهها و رسيدن به اشباع نظرى، تحليلها در دو مرحله طبقهبندى شدند و در نهايت ماحصل تحليل محتواى دادههاى

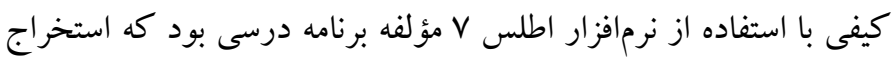

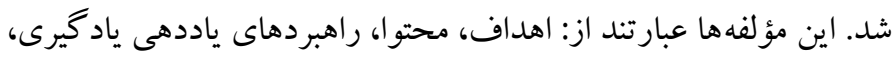
مواد و منابع آموزشى، فضا، زمان و ارزشيابى. در ادامه هر يكك از مؤلفههاى مر تبط با برنامه درسى هنر بومى منطقه سيستان

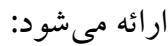
مؤلفه اهداف برنامه درسى: توجه به دانش بومى، حفظ و ارتقاء دانش و

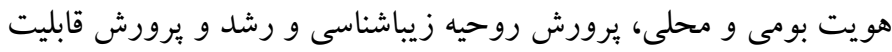
هاى وجودى براى بيان هنرى از جمله اهدافى است كه در برنامه درسى هنر بومى نسبت به تحقق آنها بايد تلاش كرد. ايجاد زمينه، امكانات و شرايط براى تحقق اين اهداف ضرورى هست. از جمله نمونههاى اهداف برنامه

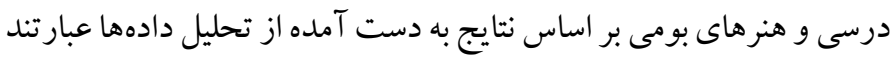

* بروش تخيل و خلاقيت

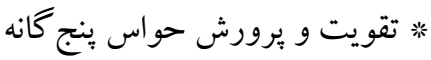

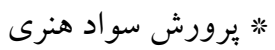

* توجه به علايق، استعداد و نيازهاى دانش آموزان

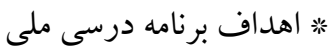

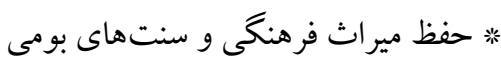

* خو استه ها و نيازهاى جامعه محلى مئى

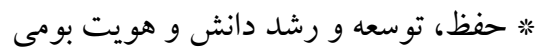

كشور ما هم با محدوديتهاى نظرى و فكرى و هم با موانع و تنكناهاى

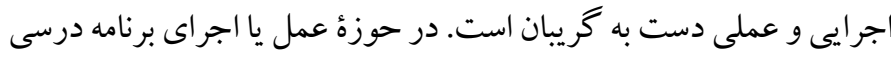
هنر دوره ابتدايى فاصله زيادى بين ايران با ساير كشورهاى منتخب در تمام عناصر برنامه درسى ديده مى شود. در بخش دوم يزوهش هايى مانند غفارى

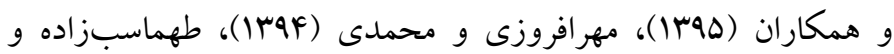

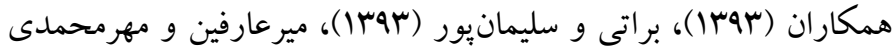

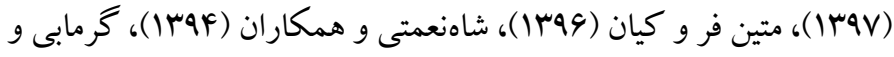

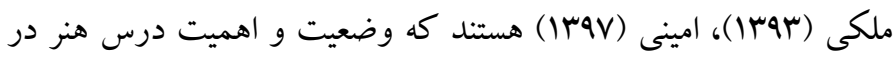
سيستم آموزشى داخل كشور و ميزان بومى شدن آن در نقاط مختلف كشور يرداختهاند. در استان سيستان و بلوجستان با وجود يِيشينه داخلى غنى و

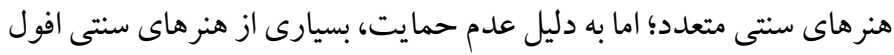

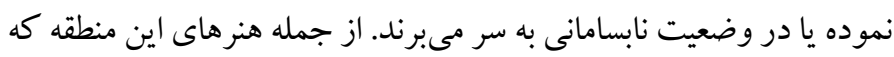

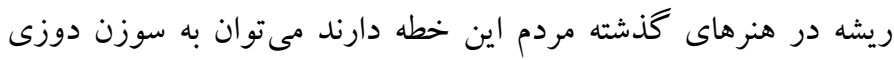

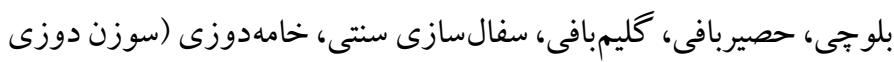

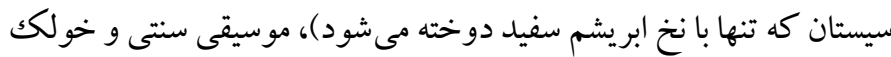
بافى (يردهبافى) اشاره نمود. ازاينرو بومى سازى برنامه درسى هنر در اين

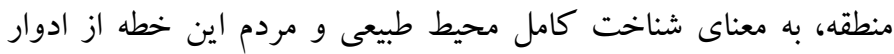

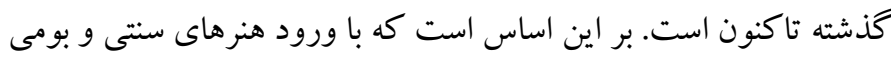
منطقه به برنامه درسى و حمايت اين هنرها كه ريشه در تاريخ اين منطقه

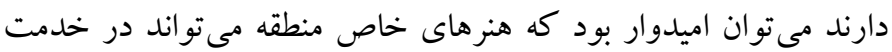

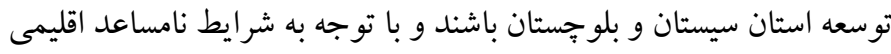

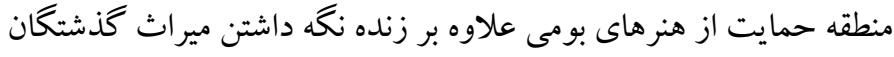

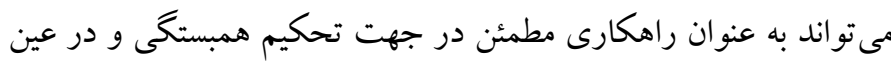

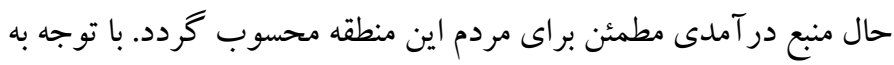

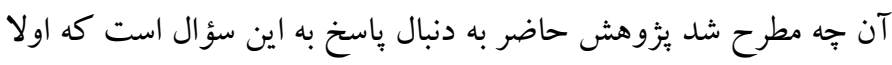
مؤلفههاى برنامه درسى هنر بومى دوره دوم ابتدايى منطقه سيستان كدامند؟ و ساختار الخوى برنامه درسى هنر بومى دوره دوم ابتدايى منطقه سيستان

$$
\text { جه ويثز گیى هايى دارد؟ }
$$

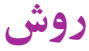

الف) طرح ئوهش و شر كت كنند كان: ماهيت يزوهش حاضر كيفى است و در دو مرحله انجام يذيرفت. در مرحله اول، اسناد، مقالات و منابع 
"** به كار گيرى روشهاى آموزشى جهت مستقل شدن دانش آموزان

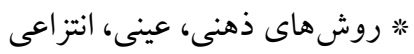

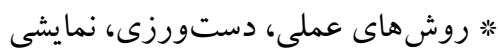

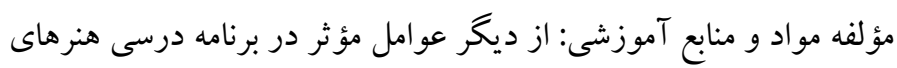

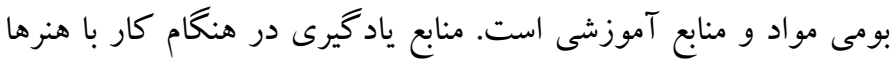

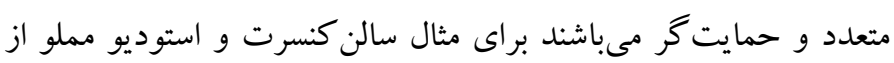

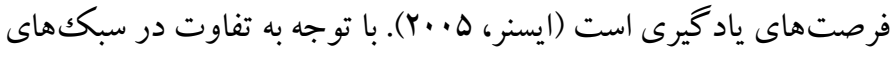

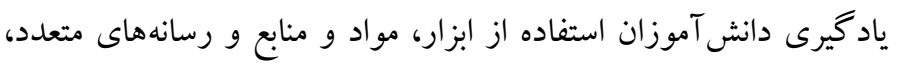
متنوع و جذاب مىتواند موجب يرورش مهارتها و توانايىهاى دانش

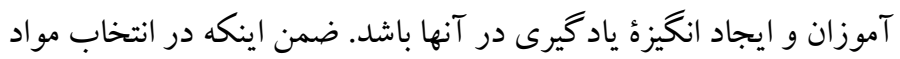
و منابع آموزشى بايد نيازهاى آموزشى و نيازهاى دانش آموزان در نظر كرفته شود و متناسب با شرايط و موقعيت ها بايد انتخاب مناسبى داشته ليابل

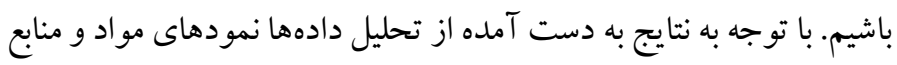

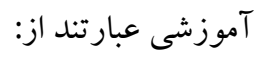

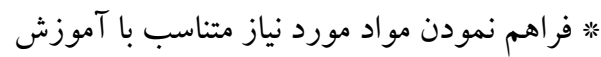

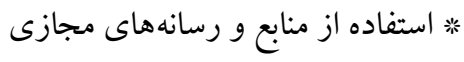
* زيبايى و جذابيت و تنوع

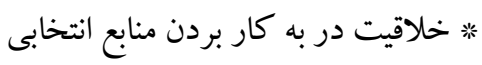

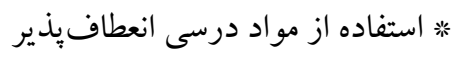

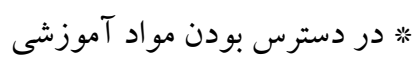

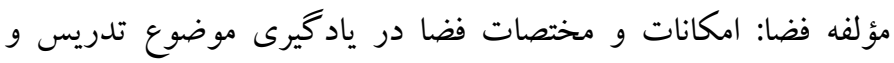
فعاليت تأثير دارد، به همين منظور بايد براى حوزههاى يادگيرى گوناگون،

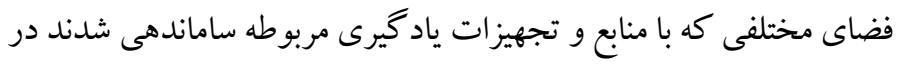

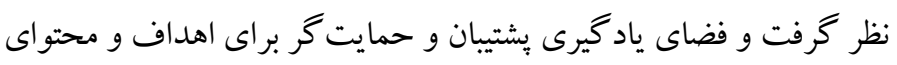

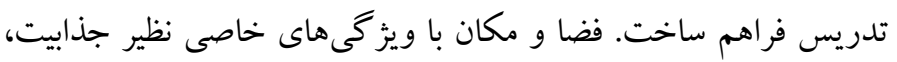

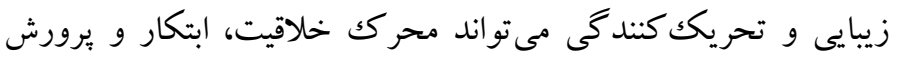
مهارتهاى خاص دانش آموزان باشد. بر اساس نتايج حاصل از تحليل داده

$$
\text { ها، ويز گى هاى فضاى ياد گيرى عبارت است ازئ }
$$

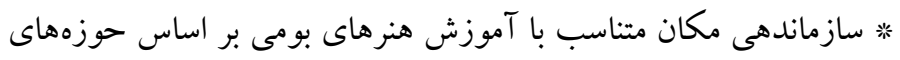

$$
\text { يادگيرى }
$$

* شاداب سازى فضاى فيزيكى و حتى عاطفى
مؤلفه محتواى برنامه درسى: يكى ديخر از عناصر مهم و حساس در آموزش دوش

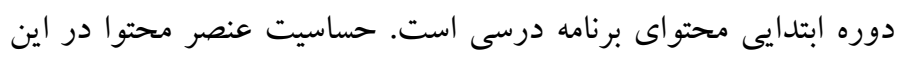

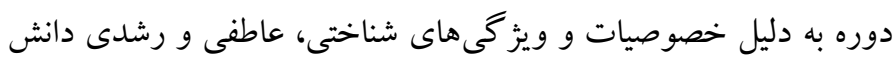

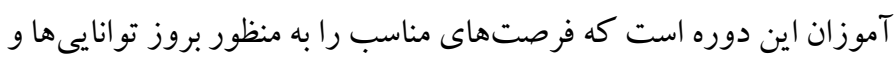
ايجاد مهارت در فراكيران فراهم مى كند. اينكه محتواى كتب درسى دور دوره

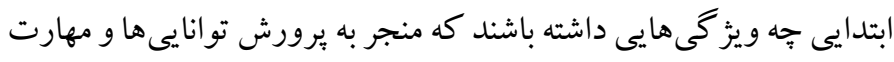

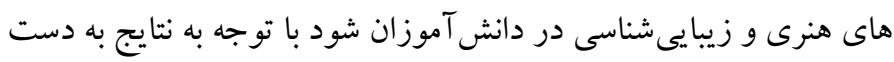
آمده از تحليل دادهها عبار تند ازي:

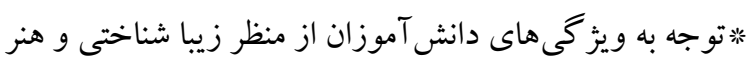

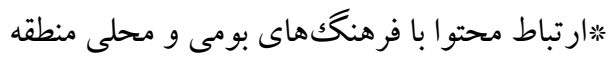

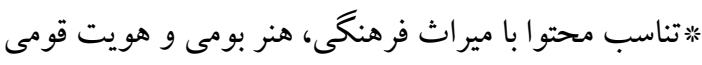
*تلفيق هنر بومى با هنرهاى مدرن و سليقه هاى جديد *تحريك و به كار گيرى تر كيبى از حواس بنج كانه

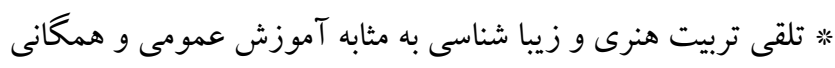
*برنامه درسى بومى منطبق با نيازهاى منطقه و كشور

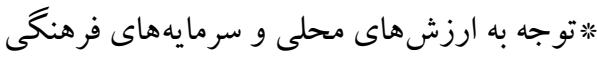

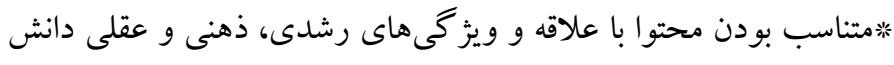
آموزان

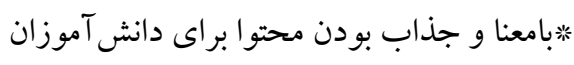

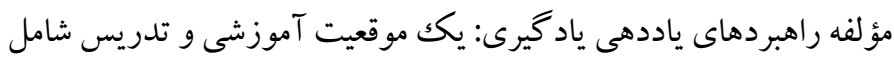

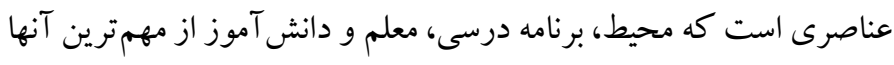

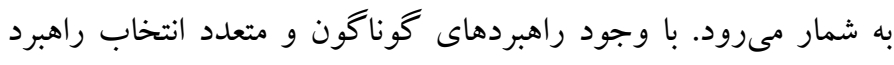
مناسب در اين زمينه بسيار مهم و داراى اهميت است؛ به همين دليل

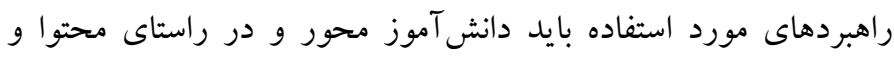
اهداف برنامه درسى و متناسب با توانايىها، علايق و سطح رشد

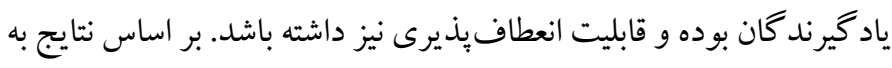

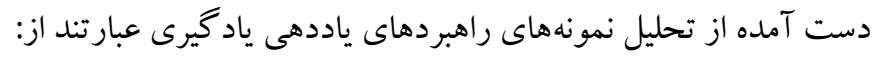

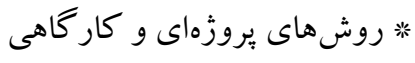

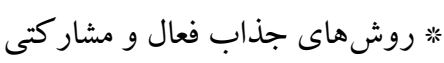
* فر اهم نمودن تجارب زيباشناسانه و خلاقانه

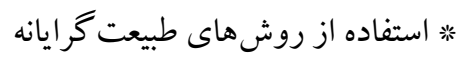
"* استفاده از روشهاى آموزشى كذشتخان 
مؤلفه ارزشيابى: ارزشيابى عنصر و مؤلفه مهم و مؤثرى در برنامه درسى هنر

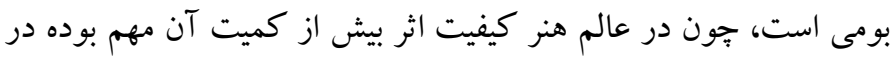

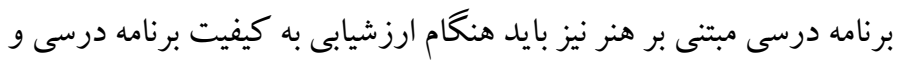

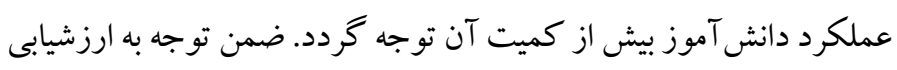

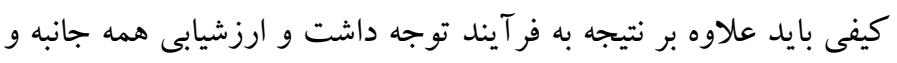

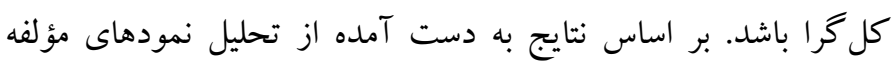
ارزشيابى عبارتند است:

$$
\text { * توجه به فر آيند ارزشيابى (ارزشيابى مستمر) }
$$$$
\text { * ارزشيابى كيفى توصيفى }
$$$$
\text { * كيفيت آثار و توليدات دانش آموزان توريفي }
$$

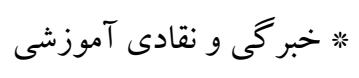$$
\text { شو مواجهه فكورانه و دقيق }
$$

$$
\text { * تحليل، ارزيابى و كاربست دانستها }
$$

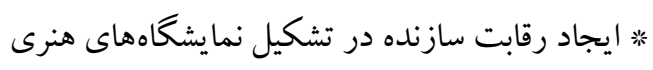

مدل برنامه درسى هنرهاى بومى منطقه سيستان و ارتباط آن با مؤلفه هايش كه از تحليل كيفى دادهها با استفاده از نرمافزار اطلس استخر مداج شد:
" ديشبينى فضاهاى واقعى براى فعاليت آزاد دانش آموزان و مشار كت آنان در تغيير محيط

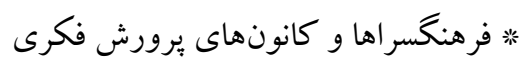
* توجه به ايجاد نمايشگاههاى هنرى * ايجاد فضايى آرام و ايمن

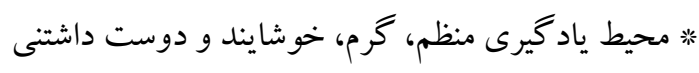

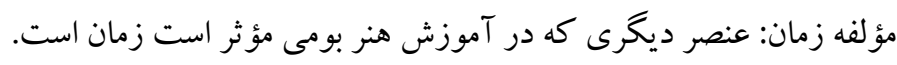

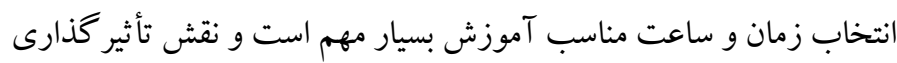

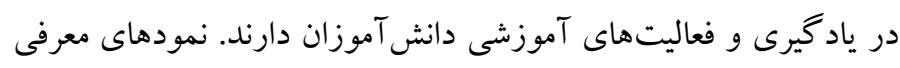
زمان بر اساس نتايج به دست آمده است تحليل عبارتند از: * بيشبينى برخى جلسات آموزشى آزاد جهت حضور داوطلبانه

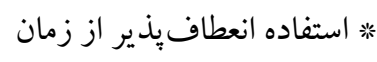

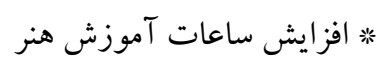
* اختصاص زمان كافى براى شركت در فعاليتهاى مدرسه و فوق برنامه * مهارت مديريت زمان

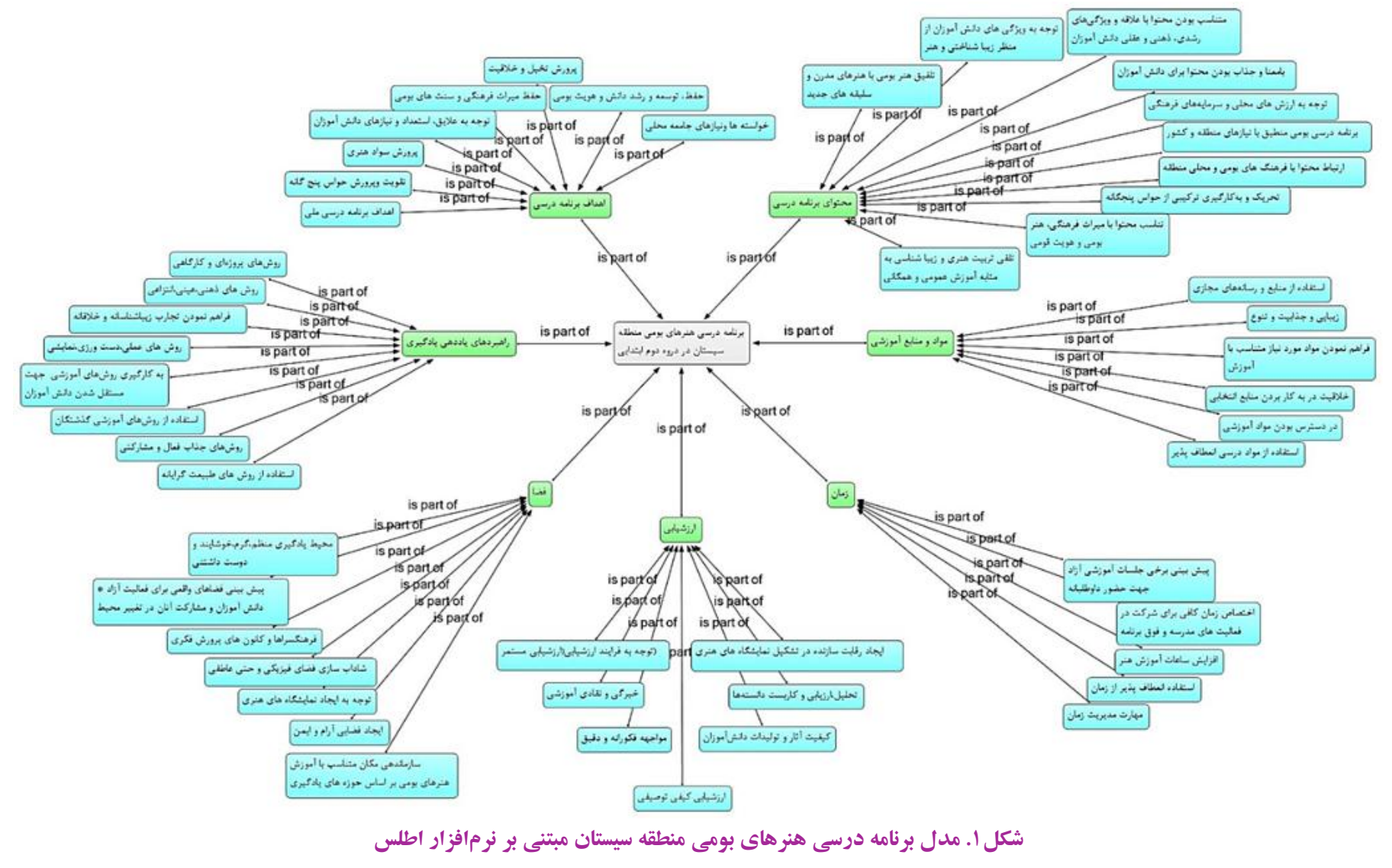


با تو جه به مؤلفه هاى شناسايى شده، الكوى ييشنهادى برنامه درسى هنرهاى بومى منطقه سيستان به صورت ذيل ترسيم شده است:

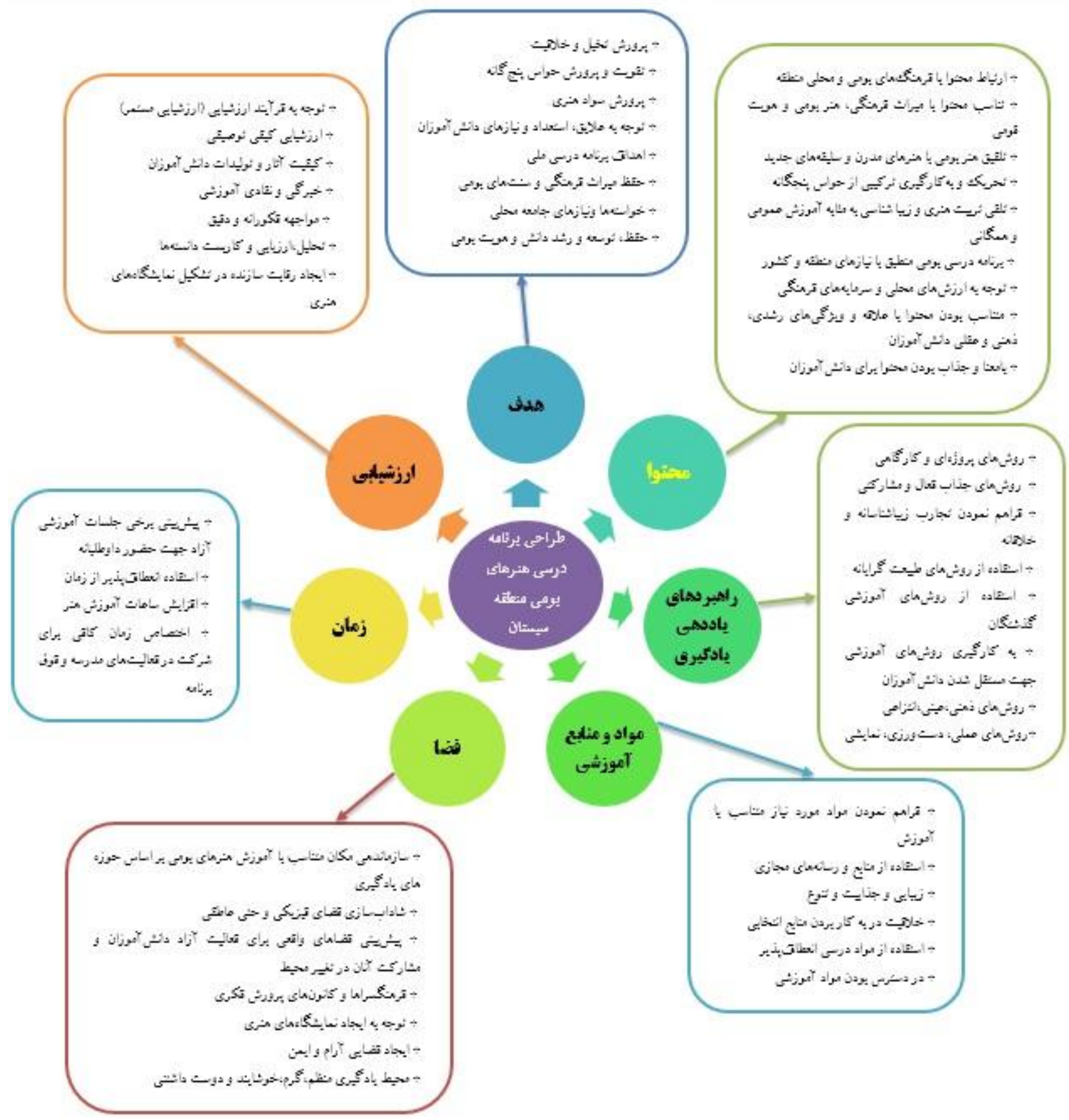

جدول r. الكوى ييشنهادى برنامه درسى هنر هاى بومى منطقه سيستان

عنوان مؤلفههاى تشكيل دهنده برنامه درسى هنرهاى بومى منطقه سيستان

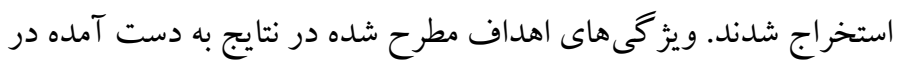

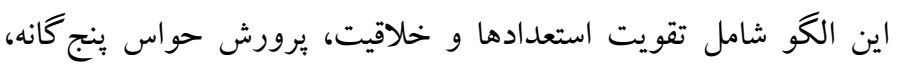
توسعه روحيه يرسشگرى و تفكر انتقادى، تحليلى فراكيران، حفظ ميراث
بحث و نتيجه كيرى يزّوهش حاضر با هدف شناسايى مؤلفهاى برنامه درسى هنر بومى منطقه

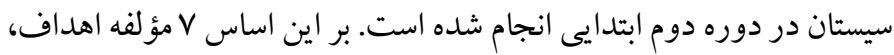

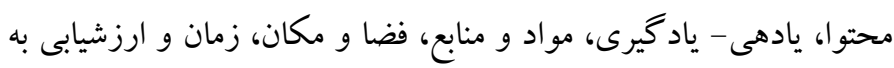


توليد هنرى را شامل آشنا شدن با مواد، ابزار و تجهيزات و فنهاى هنر و

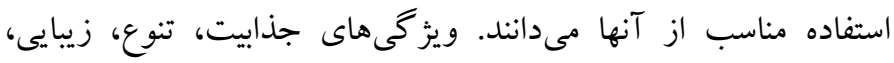
انعطاف يذيرى و در دسترس بودن را براى مواد آموزشى مهم تلقى مى كنئد.

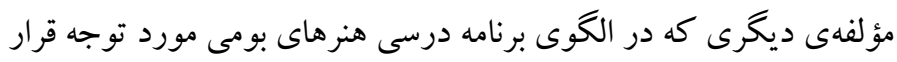

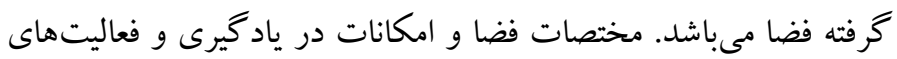

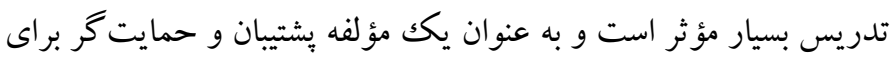
تحقق اهداف و محتواى تدريس محسوب مى شود. فضاى يادگيرى بايد

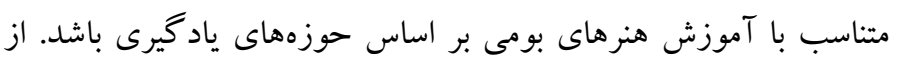

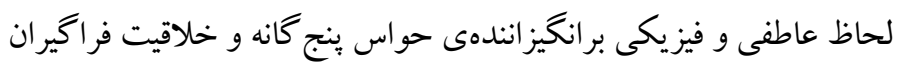

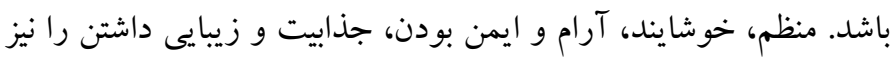

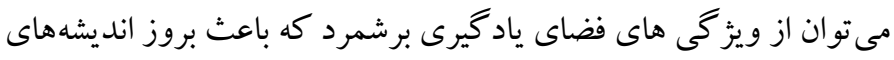

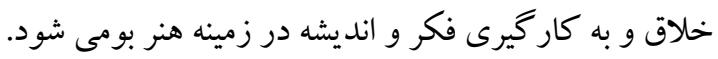

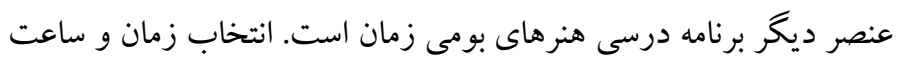

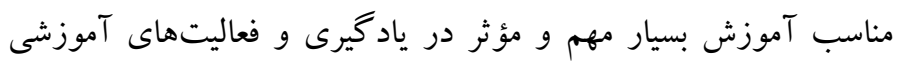

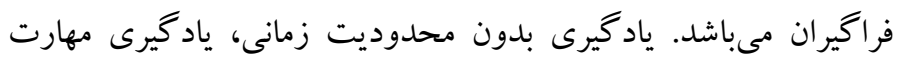
مديريت زمان، برنامهريزى بلندمدت، استفاده با برنامه از زمان، زمان و

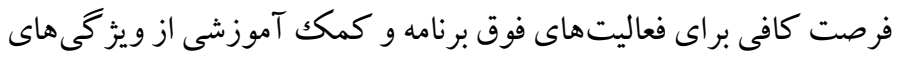

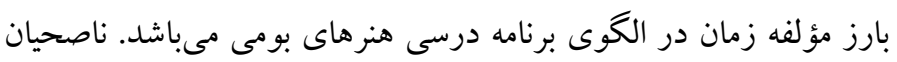

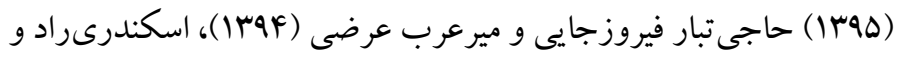

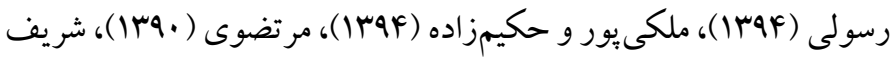
زاده (IrNV) )، شاهحسنى (IrNV) بر بيشينى جلسات آموزشى آزاد جهت

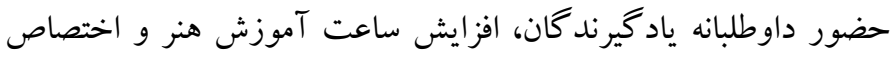
زمان كافى براى شركت در فعاليتهاى هنرى مدرسه و فوق برنامه تأكيد داشتند. يكى از عناصر مهم و مؤثر در برنامه درسى ارزشيابى مىباشد به علت اينكه . در حوزه هنر برداختن به كيفيت هنر از كميت آن ضرورى تر است الزاماً

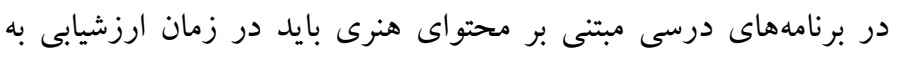

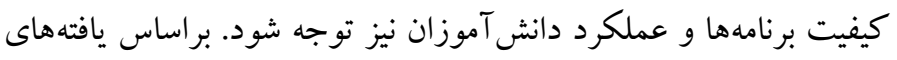
يزوهشهاى اسكندرىراد و رسولى (IMaF)، ملكى يور و حكيمزاده

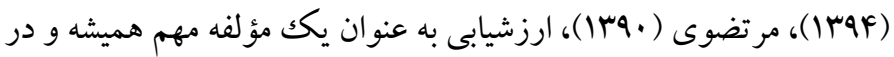

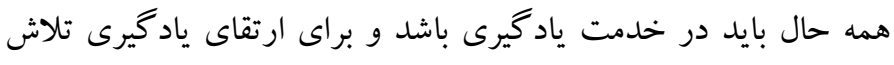

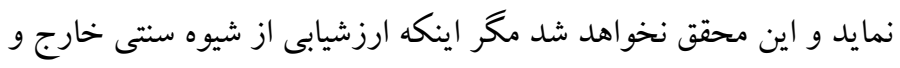

فرهنگى و سنتهاى بومى، توجه به دانش بومى و حفظ و توسعه آن،

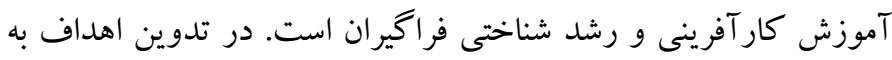
علايق، نيازها و توانيىهاى فراگيران توجه مىشود. ناصحيان (هوسا)

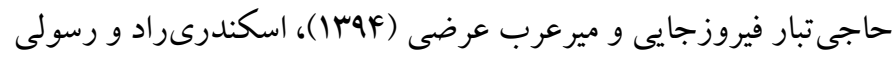

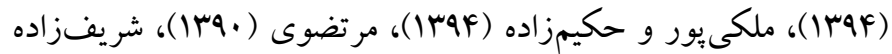
(IrAV) يرورش سو اد هنرى، تخيل و خلاقيت و حواس (ITVV) ينج گانه دانش آموزان و تلفيق هنر بومى با برنامه درسى رسمى مدرسه، رشد

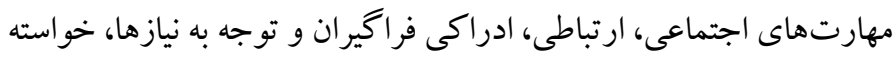

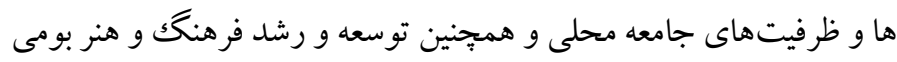

و آموزش كار آفرينى را از اهداف برنامه درسى هنرهاى بومى مى داندئ

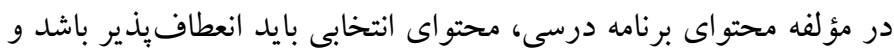

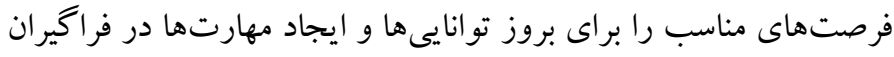

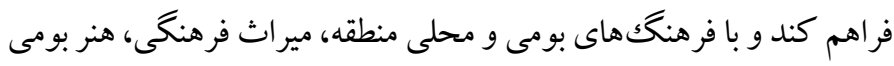

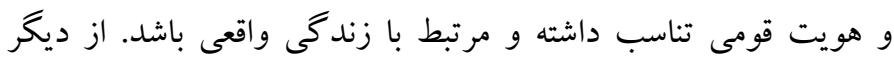

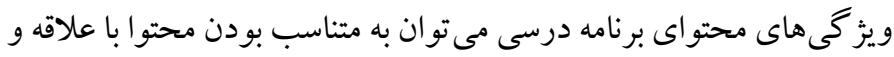

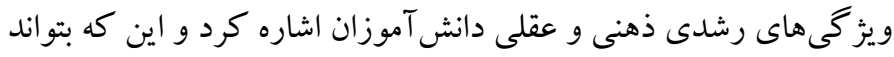
هنر بومى را با هنرهاى مدرن و سليقهاى جديد تلفيق كند. كيان و و وسئ

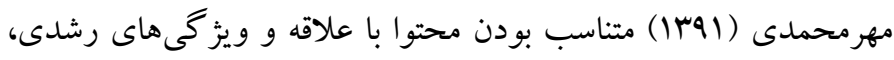

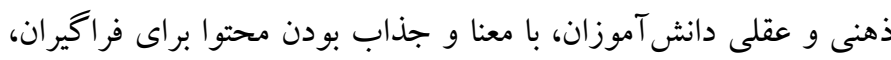

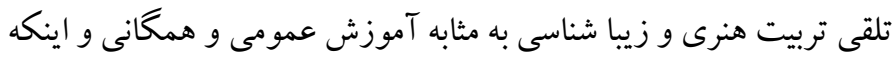

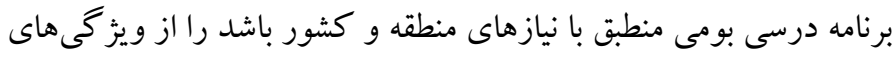
محتواى برنامه درسى هنرهاى بومى مى دانند.

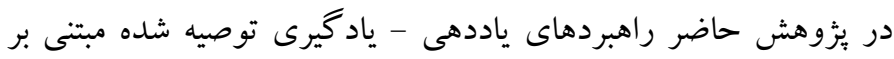

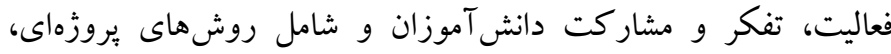

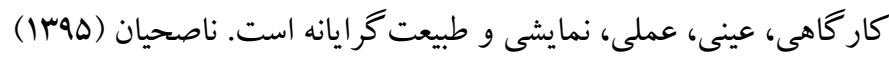

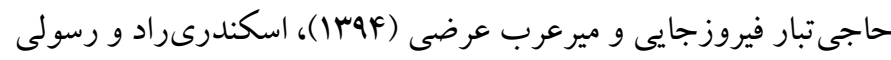

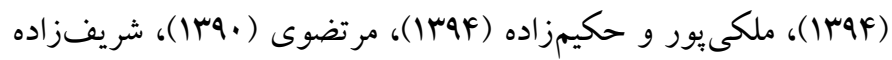

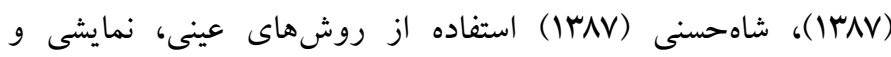

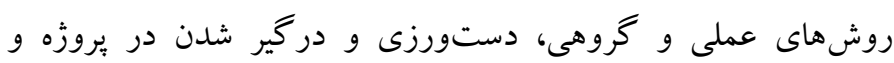
موقعيت هاى معنادار را در تربيت زيباشناسى مؤثر و مورد تأكيد مى دانند.

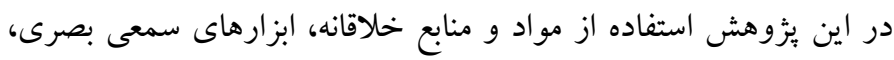

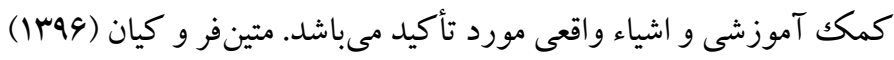


كلاس متفاوت از ساير كلاس هاى درسى است. در شيوه ارزشيابى به جاى ارزشيابى بايانى از خود ارزيابى و ارزشيابى فر آيندى كيفى توصيفى استفادي داده

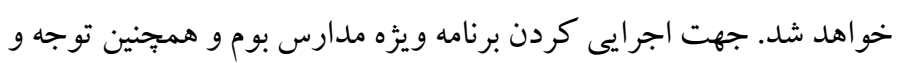

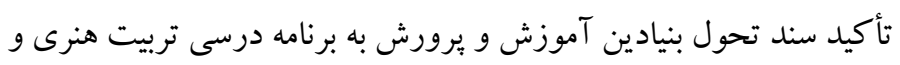

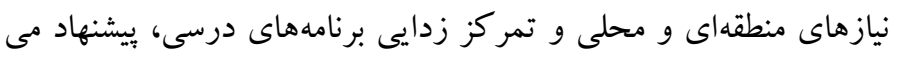

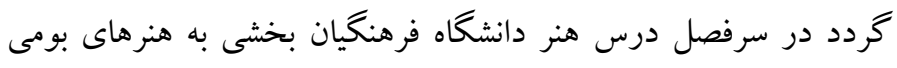

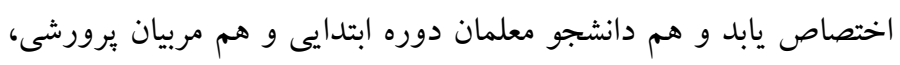
دروس تخصصى رشتههاى هنر بومى را بياموزند تا تجربيات هنرى،

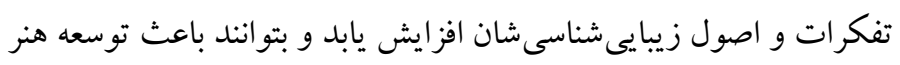

$$
\text { بومى در مدارس شوند. }
$$

ملاحضات اخلاقى يبيروى از اصول اخلاق ثئوهش: اين مقاله بر كرفته از رساله دكترى نويسنده اول در

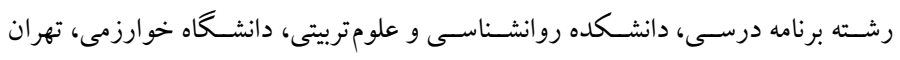

مىباشد. حامى مالى: بثزوهش حاضر فاقد حمايت مالى بوده است. نقش هر يكك از نويسند كان: نويسنده اول محقق اصلى اين يثزوهش است. نويسنده دوم و سوم اساتيد راهنماى اول و دوم و نو يسنده جهارم استاد مشاور بودهاند. تضاد منافع: نويسند گان مقاله هيج تضاد منافعى در راستاى اين تحقيق اعلام نمى كنند. تشكر و قدردانى: از اداره كل ا ستان سيستان بلوجِستان و كار شنا سان مربوطه كه در انجام تحقيق همكارى لازم را داشتهاند تشكر و قدردانى مى أشود.
فر آيند محور و كيفى شود. طراحى موقعيتها و فعاليتها كمكك مى كند

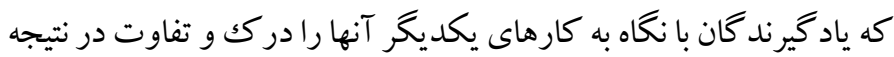
و محصول را ارزيابى كنند و زمينه را براى خبر گحى فراهم آورند.

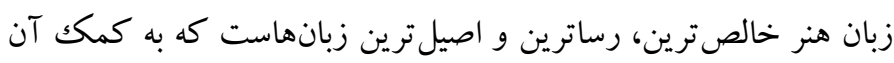

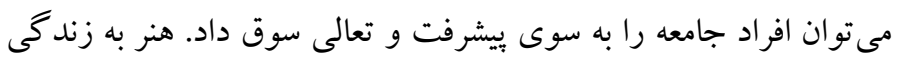

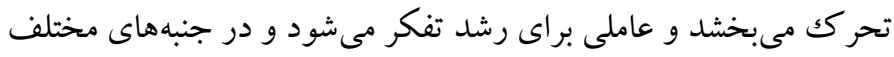

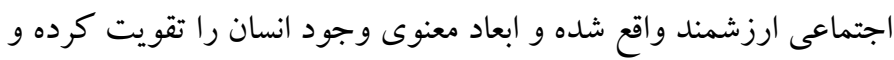

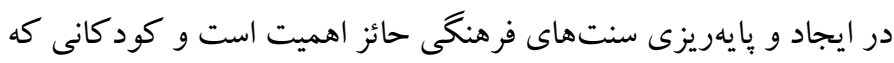

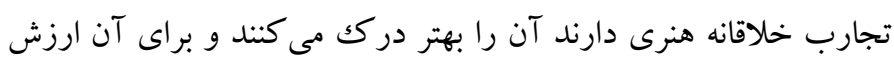
بيشترى قائل هستند؛ زيرا ذوق و خلاقيت هنرى براى آنان معنىدارتر است. بنابراين ضرورى است براى برورش استعداد هنرى و روحية زيباشناسى

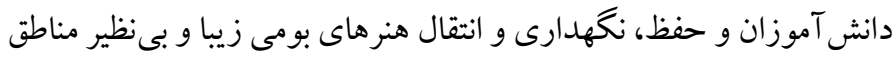

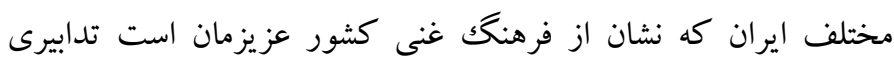

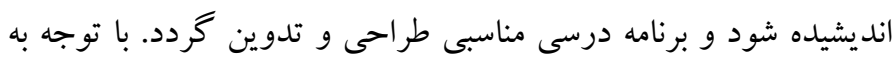

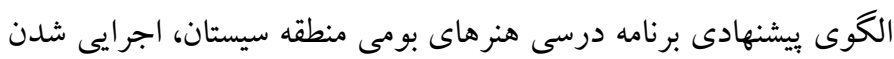

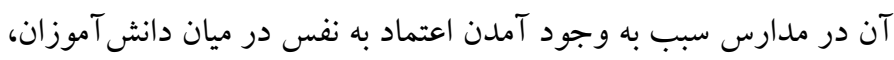
رشد خلاقيت، افزايش مهارتهاى حسى و حركتى، افزايش روحيه

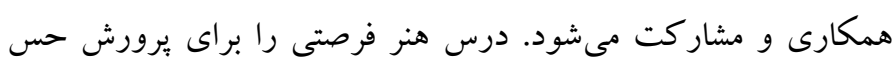

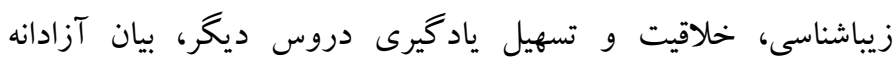
احساسات، ابراز وجود و ارائه تجربههاى شخصى را فراهم مى آورد. زمان يان

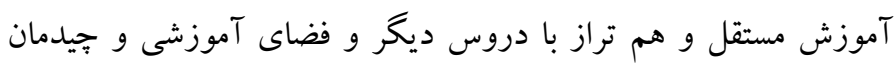




\section{References}

Abedi, Lotfali and Mehr Mohammadi, Mahmoud. (2012). The nature of teaching and its aesthetic dimensions. Modares Quarterly, Volume 5, Number 3. (persian). [link]

Ahangari Kalaei, Zahra and Rahbari, Fatemeh and Sarvari, Fariba (2016). A Comparative Study of Primary Art Education in Iran and Japan, National Conference on Science and Technology of Psychology, Educational Sciences and Comprehensive Psychology of Iran, Tehran. (persian). [link]

Bamford, A. (2018).The Wow Factor: Global research compendium on the impact of the arts in education, Waxmann Verlag, pp.17-18. [link]

Garmabi, Hassan Ali Maleki, Hassan Beheshti, Saeed Afkhami, Reza (2017). Design and validate the native model of the elementary school curriculum based on the components of aesthetics and art. Volume 1, Number 2, pp. 32-1. (persian). [link]

Ghaffari, Khalil Kazempour, Ismail (2016). The Impact of Discipline-Based Art Education Curriculum on Artistic Education of Elementary Students, Research in Curriculum Planning, 25 (52) Agent, Masoumeh. (persian). [link]

Hudson, Peter \& Hudson, Sue (2018). Examining Preservice Teachers' Preparedness for Teaching Art. International Journal of Education \& the Arts, Voulume 8, Number 2. [link]

Iwai, K (2019). The Contribution of Arts Education to Children's Lives, Paper presented at Preparedness for Teaching Art, International Journal of Education $\&$ the Arts, Volume 8 Number 2. [link]

Kian, Marjan. Mehr Mohammadi, Mahmoud (2015). Designing and validating the optimal model of Iranian elementary school art curriculum, Iranian Curriculum Studies Quarterly, 6 (21). (persian). [link]

Kian, Marjan., Mehr Mohammadi, Mahmoud (2017). Identifying the neglected aspects and dimensions of the elementary school art curriculum, two scientificresearch quarterly journals of Shahed University, 20 (3). (persian). [link]

Liu, H (2018). Practical Teaching Research of College Art Design, Informatics and Management Science I, Lecture Notes in Electrical Engineering, Volume 613, pp 222-284. [link]

Matin Far, Narges. Kian, Marjan. (2017). A Review of Elementary Teaching Methods Based on Integrated Art Curricula, First National Conference on New Findings. (persian). [link]
Mehr Mohammadi, Mahmoud (2012). Designing an Art Education Model in the Elementary School, AlZahra University Humanities Quarterly, 11 (39). (persian). [link]

Mehrafarzi, Ali Mohammadi, Isa The effect of art education in primary schools (2016). A Comparative Study of Primary Art Education in Iran and Japan, National Conference on Psychology Science and Technology, Educational Sciences and Comprehensive Psychology of Iran, Tehran. (persian). [link]

Mir Arifin Fatemeh Sadat, Mehr Mohammadi Mahmoud, Ali Asgari Majid, Haji Hosseinnejad Gholamreza (2018). Design and approval of the course "Aesthetic approach to education" for the teacher education program. Journal of Curriculum Studies (J.C.S.), Volume 14, Number 54 119 - V9 . (persian). [link]

Mortazavi, Mehdi (2014). Archaeological Localization and Traditional Arts: A Case Study of Sistan and Baluchestan Province, Archaeological Letter, 2 (2). (persian). [link]

Shah Nemati, Zahra. Prosperous, Venus. (2016). Analysis of Art Teaching Methods in order to provide a favorable model in the elementary school of Iran, Quarterly Journal of New Approach in Educational Management, 8 (3). [link]

Tahmasbzadeh Sheikh Lar, Davood. Alam al-Huda, Jamila (2016). Aesthetics Education: A Comprehensive Approach to Curriculum Challenges. International Conference on Humanities, Psychology and Social Sciences. (persian). [link]

Walsh, J.N (2019). Teaching Artists in the High School: A Creative Approach to Student Self-Esteem. Master's Theses. [link] 